\title{
Partisipasi Masyarakat dalam Program Pengembangan Usaha Mina Pedesaan Pengolahan dan Pemasaran Hasil Perikanan (PUMP-P2HP) \\ Bunga Chintia Utami
}

Universitas Lancang Kuning, Pekanbaru, Indonesia, 28265 Tel: (0761) 53108-53236; Fax

(0761) 52248 E-mail: bunga.chintiautami@unilak.ac.id

\section{LATAR BELAKANG MASALAH}

Pengentasan kemiskinan adalah tujuan utama pembangunan yang dilaksanakan secara bersama oleh berbagai kementrian di Indonesia. Dalam mencapai pengentasan kemiskinan secara bersama maka sejak tahun 2009 dilaksanakan sebuah program yang berbasis masyarakat. Masyarakat diharmonisasikan dan disinergikan ke dalam wadah program pemberdayaan melalui Program Nasional Pemberdayaan Masyarakat (PNPM) Mandiri. PNPM Mandiri bertujuan meningkatkan pemberdayaan masyarakat miskin supaya menyadari potensi yang dimiliki dan mengetahui kebutuhan untuk mengentaskan diri dari kemiskinan. Cakupan sasaran program dan kegiatan penanggulangan kemiskinan diperluas dengan melibatkan seluas-luasnya masyarakat dan pihak-pihak lain dalam proses pembangunan yang diimplikasikan dengan memperluas program Kluster 4 diantaranya adalah upaya Peningkatan Kehidupan Nelayan (PKN) yaitu berada dalam naungan Kementrian Kelautan dan Perikanan. Pada Tahun 2012, Kementrian Kelautan dan Perikanan memiliki 3 program yaitu Pengembangan Usaha Garam Rakyat(PUGAR), Pengembangan Desa Pesisir Tangguh(PDPT) dan Pengembangan Usaha Mina Pedesaaan(PUMD). Bagan program PNPM Mandiri Kementrian Kelautan dan Perikanan dapat dilihat seperti dibawah ini. 


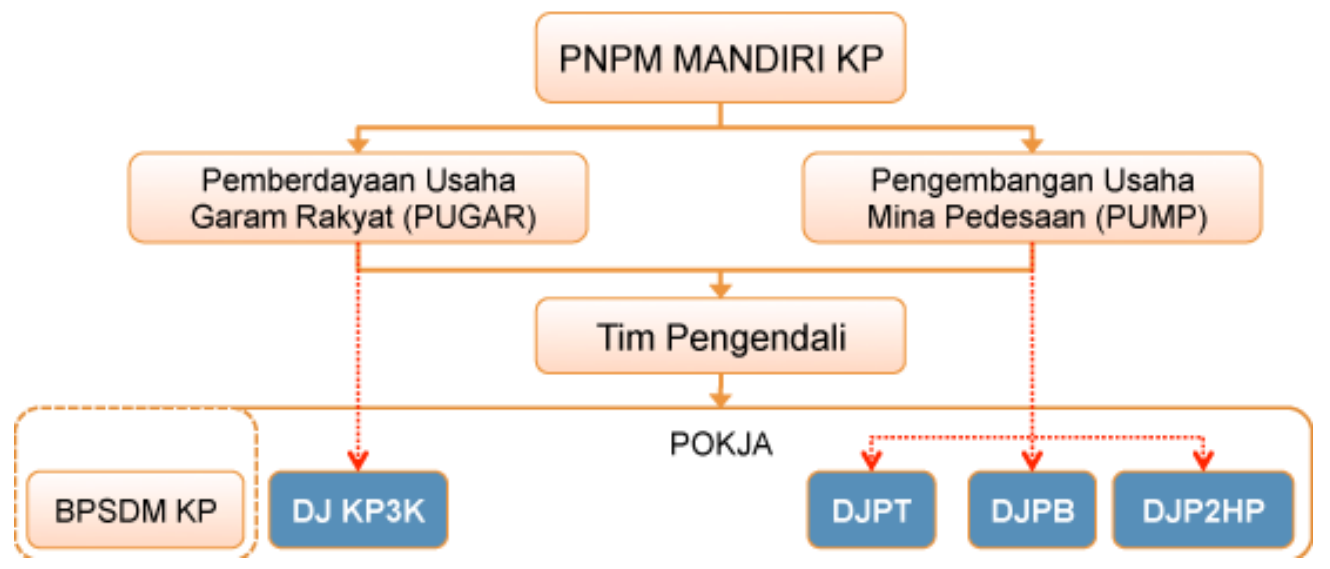

Salah satu program yang menarik untuk dikaji adalah program Pengembangan Usaha Mina Pedesaan(PUMD) yang berada dalam naungan Direktorat Jendral Pengelolahan dan Pemasaran Hasil Perikanan. Pada umumnya masyarakat hanya mengetahui program berupa bantuan modal untuk produksi dan tangkap hasil perikanan. Sehingga program ini masih belum familiar bagi nelayan.

PUMP-P2HP merupakan kegiatan pemberdayaan yang dilakukan melalui fasilitasi bantuan pengembangan usaha bagi pengolah dan pemasar hasil perikanan dalam wadah Kelompok Pengolah dan Pemasar(POKLAHSAR). POKLAHSAR merupakan kelompok usaha kelautan dan perikanan bidang pengolahan dan pemasaran sebagai pelaksana PUMPP2HP dalam penyaluran bantuan pengembangan usaha. PUMP-P2HP bertujuan untuk meningkatkan kemampuan dan mengembangkan wirausaha bidang pengolahan dan pemasaran di pedesaan melalui bantuan langsung sebesar Rp.50.000.000/kelompok. Program PUMP-P2HP bertujuan meningkatkan kemampuan usaha, penyerapan tenaga kerja serta pngembangan wirausaha pengelolaan dan pemasaran hasil perikanan. Sehingga diharapkan dapat meningkatkan unit-unit usaha baru bidang pengolahan dan pemasaran serta memberikan dampak ekonomi bagi masyarakat kelautan dan perikanan di pedesaan. Indikator Output PUMP-P2HP antara lain : 
1. Tersalurkannya Bantuan Langsung Masyarakat kepada 1.500 Kelompok Usaha Pengolah dan Pemasar (POKLAHSAR) di 146 Kabupaten/Kota.

2. Terlaksananya fasilitasi penguatan;

3. Peningkatan kapasitas kelembagaan POKLAHSAR melalui sosialisasi, pelatihan dan pendampingan.

Sedangkan outcome PUMD P2HP adalah 1) meningkatkan produksi, 2) meningkatkan pendapatan, 3) tumbuhnya wirausaha kelautan dan perikanan serta 4) meningkatnya kualitas lingkungan kelompok mandiri. Sehingga untuk mencapai keberhasilan kebijakan harus memenuhi pencapaian output dan outcaome tersebut.

Persyaratan khusus yang harus dipenuhi oleh adalah sebagai berikut:

1. Memiliki profil usaha

2. Memiliki Sumber Daya Manusia (SDM) untuk mengelola usaha mina

3. Mempunyai kepengurusan yang aktif dan dikelola oleh pengolah dan pemasaran

4. Tercatat sebagai kelompok binaan dari Dinas Kelautan dan Perikanan Kabupaten/ Kota

5. Telah beroperasi minimal 1 tahun

6. Memiliki kontinuitas pemasaran

7. Satu Kelompok Pengolah atau Pemasar (POKLAHSAR) hanya diperbolehkan mengusulkan satu jenis menu usaha PUMP-P2HP yang diprioritaskan untuk dipilih kelompoknya

8. Satu POKLAHSAR hanya berhak memperoleh satu paket menu BLM PUMP P2HP. Penyaluran bantuan PUMP P2HP kepada Poklahsar dibantu oleh Kelompok Kerja (Pokja) PUMP P2HP yang sekretariatnya berada di Direktorat Usaha dan Investasi Direktorat Jenderal P2HP, Dinas Kelautan dan Perikanan Provinsi sebagai tim Pembina, Dinas Kabupaten/kota yang membidangi kelautan dan perikanan sebagai tim teknis serta tenaga 
pendamping yang berada di Kabupaten/Kota penerima PUMP P2HP. Sehingga mekanisme penyaluran bantuan PUMP - P2HP dilaksanakan secara berjenjang mulai dari Kabupaten/ Kota, Propinsi hingga Pusat yang meliputi identifikasi, seleksi dan verifikasi data Poklahsar maupun persyaratan dokumen administrasi penyaluran PUMP P2HP. Pemanfaatan bantuan PUMP P2HP yang diterima POKLAHSAR dimanfaatkan untuk pembelian peralatan pengolahan yang telah ditentukan dalam Rencana Usaha Bersama (RUB) Poklahsar sesuai dengan kesepakatan kelompok. Dalam pemanfaatan bantuan maka peran tenaga pendamping sangat dituntut keahliannya dalam membina kelompok sehingga bantuan digunakan sesuai dengan kebutuhan anggota kelompok.

Kriteria umum kelompok usaha calon penerima BLM PUMP-P2HP adalah a. POKLAHSAR skala mikro yang melakukan usaha pengolahan dan pemasaran hasil perikanan; b. Pengurus dan anggota bukan Perangkat Desa/Kelurahan, PNS, TNI/Polri, dan Penyuluh Perikanan Tenaga Kontrak (PPTK); c. Berada di dalam satu desa yang sama atau desa yang berdekatan. d. Terdaftar di Dinas Kabupaten/Kota; e. Setiap anggota kelompok tidak boleh menerima lebih dari satu BLM PNPM Mandiri KP. POKLAHSAR dibentuk atas dasar kesamaan kepentingan, kesamaan kondisi lingkungan (sosial, ekonomi, sumberdaya) dan keakraban untuk meningkatkan dan mengembangkan usaha anggota. Jumlah pengurus dan anggota POKLAHSAR paling sedikit 5 orang. Sedangkan kriteria khusus POKLAHSAR calon penerima BLM PUMP-P2HP adalah a. Memiliki profil usaha; b. Mempunyai kepengurusan yang aktif dan dikelola oleh pengolah dan pemasar; c. Terdaftar dan mau dibina oleh Dinas Kelautan dan Perikanan Kab/Kota, yang tertuang dalam Keputusan Kepala Dinas Kab/Kota; d. Satu POKLAHSAR hanya diperbolehkan untuk mengusulkan satu jenis menu usaha PUMP-P2HP yang diprioritaskan untuk dipilih kelompoknya; e. Satu POKLAHSAR hanya berhak memperoleh satu paket menu BLM PUMP-P2HP. 
Penggunaan dana Bantuan Langsung program PUMP-P2HP hanya digunakan untuk peralatan pengelolaan dan pemasaran. Ada 12 menu bidang usaha pengelolaan dan 1 menu pemasaran. Setiap menu memiliki alokasi penggunaan dana yang berbeda. Menu tersebut meliputi beberapa pilihan yaitu:

1. Usaha Pengolahan Abon Ikan. POKLAHSAR dapat menggunakan dana BLM PUMPP2HP untuk membiayai usaha pengolahan abon ikan yang terdiri dari : a) Pembelian alat pengolahan abon ikan yang sesuai dengan standar mutu, antara lain : meja stainless, keranjang/trays, pisau, talenan akrilic, wadah pengukusan, penyerat daging, pengepres, wajan penggorengan, panci perebusan, kompor, timbangan, pembeku (freezer), penutup plastik (hand sealer), peniris (spiner), penutup plastik hampa udara (vacum sealer), dan peralatan pendukung pengolahan abon ikan lainnya, b) Pembelian bahan kemasan, c) Pembelian mesin pencetak tanggal kadaluwarsa.

2. Usaha Pengolahan Kerupuk/Snack Ikan.POKLAHSAR dapat menggunakan dana BLM PUMP-P2HP untuk membiayai usaha pengolahan kerupuk/snack ikan terdiri dari a)Pembelian alat pengolahan kerupuk/snack ikan sesuai dengan standar mutu, antara lain meja stainless, pisau, talenan akrilic, wajan penggorengan, pengaduk (mixer), penghancur (grinder), timbangan, keranjang/trays, wadah pengukusan, kompor, para-para/tampah, pemotong kerupuk, pencetak kerupuk, pembeku (freezer), peti berinsulasi (cool box), penutup plastik (hand sealer), dan peralatan pendukung pengolahan kerupuk/snack ikan lainnya, b)Pembelian bahan kemasan, c) Pembelian mesin pencetak tanggal kadaluwarsa.

3. Usaha Pengolahan Bakso Ikan. POKLAHSAR dapat menggunakan dana BLM PUMPP2HP untuk membiayai usaha pengolahan bakso ikan terdiri dari a) Pembelian alat pengolahan bakso ikan sesuai dengan standar mutu, antara lain meja stainless, pisau, talenan akrilic, penghancur (grinder), pencacah dan pengaduk (silent cutter), pencetak bakso (fish ball portable), wadah perebusan, kompor, timbangan, penutup plastik (hand 
sealer), sendok, pembeku (freezer), wadah/ember plastik, keranjang/trays, penutup plastik hampa udara (vacum sealer) dan peralatan pendukung pengolahan bakso ikan lainnya, b) Pembelian bahan kemasan, c) Pembelian mesin pencetak tanggal kadaluwarsa.

4. Usaha Pengolahan Nugget Ikan. POKLAHSAR dapat menggunakan dana BLM PUMPP2HP untuk membiayai usaha pengolahan nugget ikan terdiri dari a) Pembelian alat pengolahan nugget ikan sesuai dengan standar mutu, antara lain meja stainless, pisau, talenan akrilic, wadah pengukusan, penghancur (grinder), pencacah dan pengaduk (silent cutter), pencetak nugget, wajan penggorengan, kompor, timbangan, penutup plastik (hand sealer), pembeku (freezer), dan peralatan pendukung pengolahan nugget lainnya, b) Pembelian bahan kemasan, c) Pembelian mesin pencetak tanggal kadaluwarsa.

5. Usaha Pengolahan Kaki Naga/Ekado/Siomay. POKLAHSAR dapat menggunakan dana BLM PUMP-P2HP untuk membiayai usaha pengolahan kaki naga/ekado/siomay terdiri dari a)Pembelian alat pengolahan kaki naga sesuai dengan standar mutu, antara lain meja stainless, pisau, talenan akrilic, penghancur (grinder), pencacah dan pengaduk (silent cutter), pencetak kaki naga (fish ball portable), wajan penggorengan, kompor, timbangan, penutup plastik (hand sealer), pembeku (freezer), peti berinsulasi (cool box), dan peralatan pendukung pengolahan kaki naga lainnya, b) Pembelian bahan kemasan, c) Pembelian mesin pencetak tanggal kadaluwarsa.

6. Usaha Pengolahan Sosis Ikan. POKLAHSAR dapat menggunakan dana BLM PUMPP2HP untuk membiayai usaha pengolahan sosis ikan terdiri dari a) Pembelian alat pengolahan sosis ikan sesuai dengan standar mutu, antara lain meja stainless, pisau, talenan akrilic, penghancur (grinder), pencacah dan pengaduk (silent cutter), pencetak sosis, wadah perebusan, kompor, timbangan, penutup plastik (hand sealer), pembeku (freezer), peti berinsulasi (cool box), penutup plastik hampa udara (vacum sealer), dan 
peralatan pendukung pengolahan sosis ikan lainnya, b) Pembelian bahan kemasan,c) Pembelian mesin pencetak tanggal kadaluwarsa.

7. Usaha Pengolahan Dodol/Selai/Permen/Manisan Rumput Laut. POKLAHSAR dapat menggunakan dana BLM PUMP-P2HP untuk membiayai usaha pengolahan dodol/selai/permen/manisan rumput laut terdiri dari a) Pembelian alat pengolahan dodol/selai/permen/manisan rumput laut sesuai dengan standar mutu, antara lain meja stainless, pisau, talenan akrilic, bak perendaman, penghancur (blender), pengaduk dodol, wadah perebusan, wajan penggorengan, kompor, timbangan, penutup plastik (hand sealer), pengering (oven), penyaring, dan peralatan pendukung pengolahan dodol/selai/permen/manisan rumput laut lainnya, b) Pembelian bahan kemasan, c) Pembelian mesin pencetak tanggal kadaluwarsa.

8. Usaha Pengolahan Bandeng Tanpa Duri/Bandeng Presto. POKLAHSAR dapat menggunakan dana BLM PUMP-P2HP untuk membiayai usaha pengolahan bandeng tanpa duri/bandeng presto terdiri dari Pembelian alat pengolahan bandeng tanpa duri/bandeng presto sesuai dengan standar mutu, antara lain meja stainless, pisau, talenan acrilic, pinset, freezer, hand sealer, wadah, alat presto, dan peralatan pendukung pengolahan bandeng tanpa duri/bandeng presto lainnya, b) Pembelian bahan kemasan, c) Pembelian mesin pencetak tanggal kadaluwarsa.

9. Usaha Pengolahan Ikan Pindang. POKLAHSAR dapat menggunakan dana BLM PUMPP2HP untuk membiayai usaha pengolahan ikan pindang terdiri dari a) Pembelian alat pengolahan ikan pindang sesuai dengan standar mutu, antara lain meja stainless, pisau, talenan akrilic, kompor, wadah perebusan, ember/bak, rak penirisan, dan peralatan pendukung pengolahan ikan pindang lainnya, b) Pembelian bahan kemasan, c) Pembelian mesin pencetak tanggal kadaluwarsa. 
10. Usaha Pengolahan Ikan Kering/Asin. POKLAHSAR dapat menggunakan dana BLM PUMP-P2HP untuk membiayai usaha pengolahan ikan kering/asin terdiri dari a) Pembelian alat pengolahan ikan kering/asin sesuai dengan standar mutu, antara lain meja stainless, pisau, talenan akrilic, wadah, para-para, hand sealer dan peralatan pendukung pengolahan ikan kering/asin lainnya, b) Pembelian bahan kemasan, c) Pembelian mesin pencetak tanggal kadaluwarsa.

11. Usaha Pengolahan Ikan Panggang/Asap. POKLAHSAR dapat menggunakan dana BLM PUMP-P2HP untuk membiayai usaha pengolahan ikan panggang/asap terdiri dari a) Pembelian alat pengolahan ikan panggang/asap sesuai dengan standar mutu, antara lain meja stainless, pisau, talenan akrilic, wadah, alat pengasapan, hand sealer, bangunan pengasapan dan peralatan pendukung pengolahan ikan panggang/asap lainnya, b) Pembelian bahan kemasan, c) Pembelian mesin pencetak tanggal kadaluwarsa.

12. Usaha Kerajinan Kulit Kerang/Hasil Sampingan Perikanan Lainnya. POKLAHSAR dapat menggunakan dana BLM PUMP-P2HP untuk membiayai usaha kerajinan kulit kerang/hasil sampingan perikanan lainnya terdiri dari a) Pembelian alat kerajinan kulit kerang/hasil sampingan perikanan lainnya sesuai dengan standar mutu, antara lain pencuci kerang (molen), pemotong kerang, pelubang kerang, bor duduk, bor tangan, gerinda duduk, gerinda tangan, jet pump, mesin amplas, oven, jig saw, spray gun meiji, hand serkel, kompressor, gunting plat, tang, blok cetakan dan peralatan pendukung pengolahan ikan panggang/asap lainnya, b) Pembelian bahan kemasan

13. Usaha Pemasaran. POKLAHSAR dapat menggunakan dana BLM PUMP-P2HP untuk membiayai usaha pemasaran hasil perikanan terdiri dari a) Pembelian alat pemasaran sesuai dengan standar mutu, antara lain pisau, talenan akrilic, wadah perebusan, wajan penggorengan, kompor, keranjang/trays, timbangan, wadah/bak besar/tong, wadah/ember, akuarium, tabung gas oksigen, aerator, blower, peti berinsulasi (cool box), pembeku 
(freezer), dan peralatan pendukung pemasaran lainnya, b) Pembelian bahan kemasan, c) Pembelian sarana pemasaran bergerak (sepeda, kereta dorong/gerobak, sepeda motor roda tiga) atau tidak bergerak (display atau rak/meja pajang/etalase), d) Pembelian mesin pencetak tanggal kadaluwarsa.

Berdasarkan penjelasan diatas terlihat bahwa program PUMD P2HP bersifat Top Down sebab kebijakan ini berasal dari pemerintah Pusat yang pelaksanaannya oleh Pemerintah Daerah bersama masyarakat. Kebijakan ini dikatakan bersifat top-down sebab pemerintah Pusat menetapkan kebijakan apa yang harus dilakukan untuk mengatasi persoalan yang dihadapi nelayan sebagai cara untuk meningkatkan kemampuan nelayan terutama dalam pengelolahan dan pemasaran hasil perikanan, bahkan pemerintah telah menetapkan pilihan menu yang akan memperoleh Bantuan Langsung PUMD P2HP.

Disisi lain, pelaksanaan teknis seperti yang tercantum dalam Keputusan Direktur Jenderal Pengolahan dan Pemasaran Hasil Perikanan Nomor KEP.312/DJ-P2HP/2012 tentang Pedoman Teknis Pengembangan Usaha Mina Pedesaan Pengolahan dan Pemasaran Hasil Perikanan Tahun 2012 menunjukkan bahwa bentuk pemilihan menu dan sasaran kebijakan(POKLAHSAR) bersifat bottom-up. Pengajuan yang dilakukan oleh POKLAHSAR akan diverifikasi oleh tim pendamping dan diajukan kepada dinas Kabupaten yang kemudian diteruskan kepada pemerintah Propinsi dan pusat. Pemerintah pusat(Kementrian dan DPR) telah menetapkan 1500 paket PUMD P2HP yang akan diberikan kepada beberapa kabupaten/ Kota. Kuota untuk setiap Kabupaten/Kota berbeda tergantung kebijakan pemerintah pusat.

Salah satu Kabupaten yang mendapat bantuan PUMD P2HP adalah kabupaten Bogor. Kementrian Kelautan dan Perikanan memberikan bantuan senilai total Rp 5,6 miliar untuk pengembangan usaha perikanan di Kabupaten Bogor di antaranya 65 paket PUMP Perikanan Budidaya senilai Rp 4,225 miliar, enam paket PUMP P2HP senilai Rp 300 juta, sarana dan prasarana pemasaran ikan hias senilai Rp 190 juta, sarana pemasaran hasil perikanan senilai 
Rp 48 juta, 250 botol vaksin Hydrovac Aeromonas senilai Rp 18,75 juta. Hal itu dikarenakan Bogor memiliki potensi besar dalam budidaya perikanan dan mampu memasok $60 \%$ kebutuhan ikan budidaya air tawa di Jakarta, Bogor, Depok, Tangerang, dan Bekasi (Jabodetabek).

Latar belakang Pemerintah menciptakan program PUMD P2HP untuk peningkatan produksi pengelolaan dan peningkatan pendapatan nelayan. Peningkatan produksi pengelolaan dan pemasaran diharapkan mampu menambah nilai jual produk hasil perikanan. Sehingga akan mencapai pengentasan kemiskinan nelayan. Selain itu, peningkatan kualitas dan kuantitas hasil perikanan diharapkan mampu meningkatkan kualitas kesehatan masyarakat karena ikan memiliki kandungan protein tinggi dan kandungan gizi lainnya. Sehingga diperlukan peningkatan ketersediaan produk olahan berbasis ikan yang beragam. Peningkatan konsumsi ikan akan berdampak pada pengentasan kemiskinan yang berupa kemiskinan kualitas gizi(kesehatan).

Kebijakan PUMD P2HP mendapat respon yang berbeda dari masyarakat dalam melihat program bantuan langsung tersebut yaitu masyarakat yang menganggap program ini kurang sesuai dan masyarakat yang menganggap program ini sudah memberikan dampak langsung bagi proses pengelolahan dan pemasaran. Hal itu seperti yang diungkapkan oleh Bapak Nosan (Ketua POKLAHSAR Sawah Murti, Desa Bojong, Kecamatan Parung, Bogor) bahwa belum ada perubahan peningkatan yang berarti dalam proses pengelolahan sebab kelompok sudah memiliki kolam ikan sebagai alternatif pembeku (freezer) dan peti berinsulasi (cool box) serta penggunaan kompor gas pengganti tungku kayu serta wadah perebusan berupa panci sebagai pengganti gentong air dirasa tidak memberi manfaat besar dalam proses pengelolaan. Kolam ikan tersebut biasanya menjadi tempat penyimpanan alami untuk ikan yang akan dijadikan olahan. Kelompok Sawah Murti memiliki kendala dalam kekurangan modal untuk menambah jumlah ikan yang akan dikelola tetapi dalam aturan 
PUMD P2HP hanya boleh digunakan untuk membeli peralatan pengelolaan. Sehingga Kelompok ini menganggap kebijakan belum menyelesaikan persoalan inti.

Sedangkan masyarakat yang menganggap pogram PUMD P2HP adalah program yang tepat dan bermanfaat sebab terjadi perbedaan proses pengelolaan antara sebelum ada kebijakan dan sesudah ada kebijakan PUMD P2HP. Hal itu seperti yang diungkapkan oleh Bapak Entong (Ketua POKLAHSAR Mandiri, Desa Bojong, Kecamatan Parung, Bogor) bahwa dalam segi proses pengolahan ada manfaat berupa penghematan biaya transportasi sebab sebelum ada bantuan langsung yang digunakan untuk Freezer box maka pengelola ikan Pindang harus melakukan pembelian ikan dengan jarak tempuh kurang lebih 80KM setiap hari, sedangkan dengan adanya 2 freezer box maka pembelian ikan dapat dilakukan sekali dalam 2 atau 3 hari. Hal itu menunjukkan bahwa ada penghematan biaya transportasi dan waktu. Selain itu PUMD P2HP juga dianggap telah memberikan pengetahuan tambahan kepada kelompok mengenai bagaimana cara peningkatan kualitas hasil pengelolaan ikan pindang melalui peningkatan tekhnologi peralatan yang digunakan seperti penggunaan panci yang dapat meningkatkan kualitas ikan dibandingkan penggunaan drum/gentong air besi yang rawan berkarat dan dapat mengancam kesehatan pembeli.

Dari segi peningkatan hasil produksi antara sebelum kebijakan PUMD P2HP dapat dilihat dari peningkatan rata-rata 10\% pada PUMD P2HP 2011 tetapi untuk program PUMD P2HP tahun 2012 masih dalam tahap pencairan dana bahkan masih ada yang belum selesai terlaksana seperti yang dialami POKLAHSAR Mandiri. Sehingga untuk peningkatan produksi pengelolaan belum terukur. Peningkatan pembelian masyarakat juga belum terlihat sebab POKLAHSAR yang di Bogor tidak melakukan perubahan dalam segi pemasaran.

Perbedaan pandangan mengenai manfaat yang timbul antara sebelum ada kebijakan dan sesudah kebijakan yang terjadi tersebut dianggap wajar sebab pemahaman dan kondisi masyarakat(POKLAHSAR) berbeda. Pengelolaan Ikan Pindang yang dilakukan oleh kedua 
POLAKHSAR berkisar 300Kg setiap pengelolaan dengan kondisi pendidikan pengelola yang hampir sama yaitu pendidikan rendah(tidak tamat sekolah wajib belajar 9 tahun) sehingga pemahaman mengenai manfaat Bantuan Langsung PUMD P2HP berbeda serta kemampuan dasar Kelompok dalam mengelola Ikan Pindang juga berbeda.

\section{Mekanisme Partisipasi Masyarakat dalam perencanaan Kebijakan}

Partisipasi berasal dari bahasa Belanda yaitu Participation yang sebenarnya berasal dari bahasa latin participacio. Parc adalah bagian dan capere berarti mengambil bagian. Partisipasi yang dilakukan masyarakat berbeda-beda tingkatannya, akibat dari perbedaan skala kegiatan. Partisipasi disebabkan antara lain partisipasi karena paksaan(manipulative participation), partisipasi dengan kekuasaan dan ancaman (coercive participation), partisipasi karena adanya dorongan (indiced participation), partisipasi yang bersifat pasif (passive participation) dan partisipasi secara spontan (spontaneous participation). Berdasarkan kategori tersebut maka kebijakan PUMD P2HP tergolong partisipasi yang disebabkan karena adanya dorongan. Dorongan berupan insentif yang diberikan berupa Bantuan Langsung sehingga Kelompok Pengelola dan Pemasar diharapkan mendaftarkan diri sebagai usaha Pengelola dan Pemasar ke Dinas perikanan setempat dan menyiapkan Rencana Usaha bersama seperti yang ditetapkan oleh Kementriaan Kelautan dan Perikanan.

Sedangkan dari segi bentuk, partisipasi memiliki dua bentuk, yaitu partisipasi horizontal dan partisipasi vertical. Dimaksud dengan partsipasi horizontal adalah masyarakat mempunyai kemampuan untuk berprakarsa, dimana setiap anggota masyarakat dapat berpartisipasi secara sejajar satu dengan yang lain, baik dalam melakukan usaha bersama ataupun dalam rangka melakukan kegiatan dengan pihak lain. Sedangkan partisipasi vertikal adalah masyarakat terlibat atau mengambil suatu bagian dalam suatu program dari pihak lain, dimana masyarakat berada pada posisi sebagai bawahan, klien dan pengikut. Progam PUMD P2HP memiliki 2 bentuk tersebut secara bersamaan yaitu masyarakat(POKLAHSAR) yang 
sebagai klien/pengikut menjadi partisipasi dalam bentuk vertical dan masyarakat sebagai tenaga Pendamping menjadi bentuk partisipasi Horizontal yaitu sebagai partner pemerintah Kabupaten/Kota.

Cub Du Sahel (dalam Mikkelsen,2001:69-70) mendeskripsikan pendekatanpendekatan dalam pelaksanaan partisipasi terbagi atas 1)Partisipasi pasif berupa pelatihan dan informasi. Pendekatan" kami lebih tahu apa yang baik bagimu”. Komunikasi satu arah seperti antara guru dan murid yang diterapkan antara staff proyek dan masyarakat.2) Partisipasi aktif.Pendekatan pelatihan dan Kunjungan”. Dialog dan komunikasi dua arah memberikan kepada masyarakat kesempatan untuk berinteraksi dengan petugas penyuluh dan pelatih dari luar.3) Partisipasi dengan keterikatan. Pendekatan"kontak,tugas yang dibayar". Bila anda melakukan ini, maka proyek akan melakukan itu. Masyarakat setempat, baik sebagai pribadi ataupun kelompok kecil,diberikan pilihan untuk terikat pada sesuatu dengan tanggung jawab atas setiap kegiatan pada masyarakat atau proyek. Model ini memungkinkan untuk beralih dari model klasik kepada model yang diberi subsidi, dimana panitia setempat bertanggung jawab atas pengorganisasian dan pelaksanaan tugas. Manfaatnya: dapat dibuat modifikasi seiring yang di inginkan. 4) Partisipasi atas permintaan setempat Kegiatan yang didorong oleh permintaan Kegiatan yang berfokus untuk menjawab kebutuhan masyarakatsetempat, bukan kebutuhan yang dirancang dandisuarakan pihak luar. Kegiatan bukanlah proyek yang tipikal: tidak ada sarana untuk suatu periode tertentu, tidak ada rencana dan struktur proyek dan tidak ada komando satuarah dari proyek kepada kelompok sasaran. Masalahnya:Bagaimana masyarakat setempat dapat memberi perhatian terhadap sesuatu yang baru dan berbeda, apabila sebelumnya mereka tidak mengetahui apapun mengenai apa yang akan terjadi.

Peran serta masyarakat bertujuan untuk menghasilkan masukan dan presepsi yang berguna dari masyarakat yang berkepentingan (public interest) dalam rangka meningkatkan 
kualitas pengambilan keputusan. Kebijakan publik yang melibatkan masyarakat yang potensial terkena dampak akibat kebijakan dan kelompok kepentingan (interest group) maka para pengambil keputusan dapat menangkap pandangan, kebutuhan dan pengharapan dari masyarakat dan kelompok tersebut untuk menuangkannya kedalam suatu konsep. Sehingga apa yang diinginkan atau dibutuhkan masyrakat terpantul langsung dalam kebijkan yang dibuat. Pandangan dan reaksi masyarakat juga akan menolong pengambil keputusan (stakeholder) untuk menentukan prioritas, kepentingan dan arah dari berbagai faktor.

Oleh karena itu, dalam Peraturan Menteri Pemberdayaan Aparatur Negara nomor 4 tahun 2011 menjelaskan bahwa ada beberapa tahapan dalam kebijakan yang harus melibatkan partisipasi masyarakat yaitu dalam menetapkan isu kebijakan dan proses publik ketiga dan proses publik keempat. Isu kebijakan adalah masalah atau kebutuhan masyarakat yang sudah atau sedang muncul atau yang berpotensi akan muncul dimasa depan. Dalam tahap ini pemerintah harus responsif dan melibatkan masyarakat sebagai pihak yang mengalami persoalan.

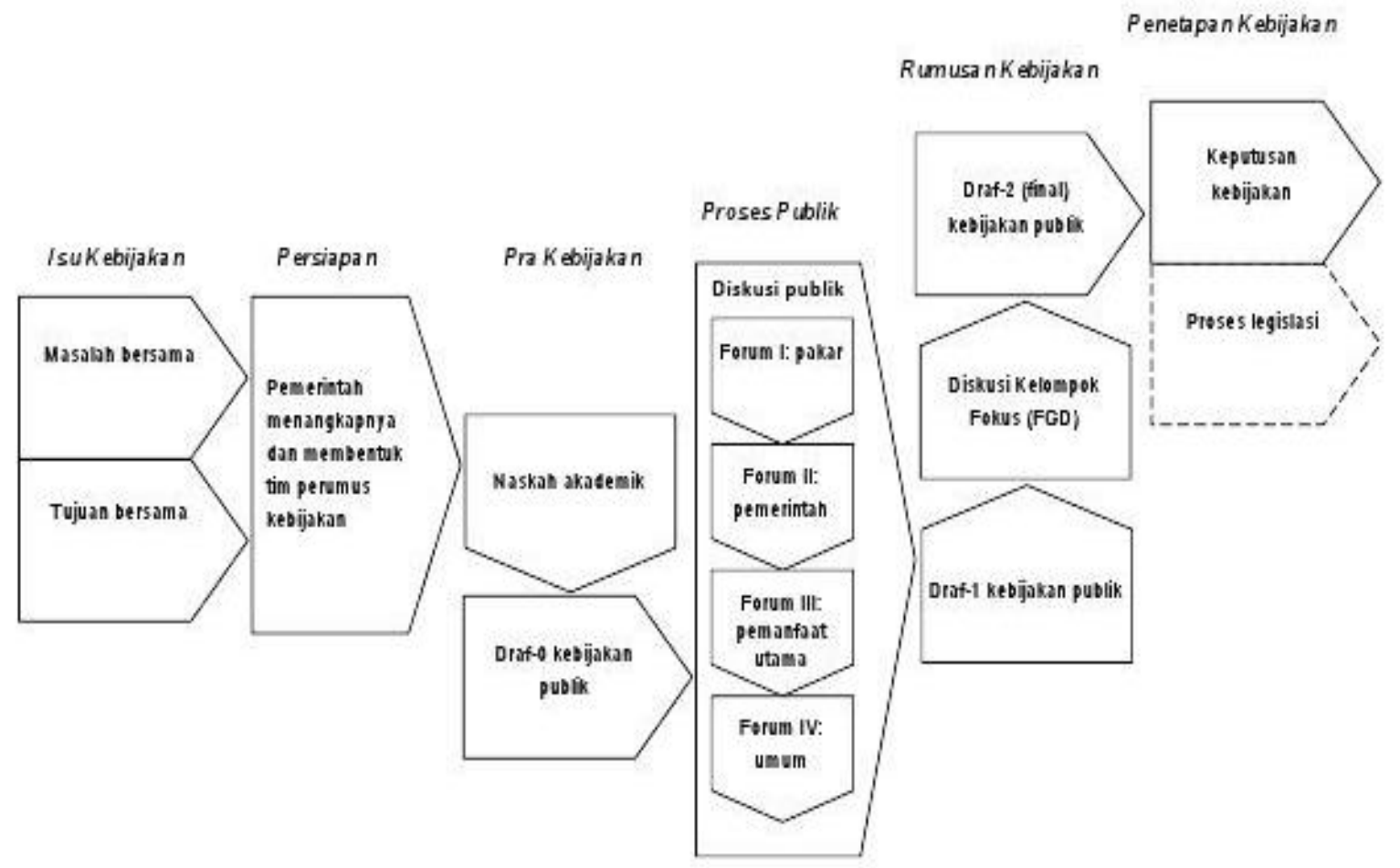


Proses Publik Ketiga adalah proses yang melibatkan pihak terkait(beneficier) yang terkena langsung oleh dampak kebijakan untuk melihat tanggapan dari mereka. Pada tahapan ini dapat dilakukan dalam bentuk diskusi publik tahap awal. Sedangkan proses Publik Keempat adalah proses yang melibatkan seluruh masyarakat untuk mendapat masukan mengenai kebijakan yang dibuat.

PUMD P2HP secara garis besar merupakan kebijakan yang bersifat Top-Down sehingga tidak ada partisipasi masyarakat dalam perencanaan dan pembuatan kebijakan ditingkat pusat. Namun secara teknis pelaksanaan di daerah, partisipasi masyarakat masih diberikan peluang. Berdasarkan pedoman PERMENPAN dan realita yang terjadi pada PUMD P2HP di Bogor terlihat bahwa ada beberapa tahapan yang tidak metibatkan partisipasi masyarakat seperti yang seharusnya. Pada petunjuk teknis pedoman pelaksanaan PUMD P2HP disebutkan bahwa ada bagian/tahapan yang melibatkan aspirasi masyarakat yaitu seperti yang tercantum dalam strategi operasional dan Ruang Lingkup. Strategi Operasional PUMP-P2HP adalah:

1. Sosialisasi tingkat Pusat, Provinsi dan Kabupaten/Kota;

2. Rekrutmen tenaga pendamping;

3. Identifikasi POKLAHSAR oleh Tenaga Pendamping untuk dilakukan seleksi dan verifikasi oleh Tim Teknis dan diusulkan oleh Kepala Dinas Kabupaten/Kota kepada Kepala Dinas Provinsi dan diteruskan ke Pokja PUMP-P2HP, selanjutnya untuk ditetapkan melalui Keputusan Dirjen

4. Penyiapan SDM melalui peningkatan kompetensi tenaga pendamping dan POKLAHSAR;

5. Verifikasi RUB oleh Tenaga Pendamping dan Tim Teknis sebagai dasar pengusulan pencairan BLM PUMP-P2HP;

6. Pelaporan dapat dilakukan melalui email, surat, fax dari tenaga pendamping kepada Pokja PUMP P2HP. 
Ruang Lingkup Kegiatan meliputi:

1. Sosialisasi dan Koordinasi Kegiatan;

2. Identifikasi, seleksi, verifikasi dan penetapan calon POKLAHSAR penerima BLM

3. Rekrutmen Tenaga Pendamping oleh BPSDM KP

4. Pelatihan dan pembekalan Tenaga Pendamping

5. Penyusunan dan Pengusulan RUB dan dokumen administrasi

6. Penyaluran BLM

7. Pendampingan oleh Tenaga Pendamping

8. Pembinaan dan Pengendalian

9. Pemantauan dan Evaluasi

10. Pelaporan.

Berdasarkan strategi operasional dan ruang lingkup kebijakan menunjukkan bahwa seharusnya kebijakan ini sudah mencerminkan isi PERMENPAN no 4 tahun 2011 tentang partisipasi masyarakat dalam perencanaan kebijakan, pengambilan keputusan dan pemantauan. Petunjuk teknis menunjukkan partisipasi masyarakat dalam sosialisasi isu dan kebijakan serta penetapan tenaga pendamping. Sosialisasi kebijakan merupakan tahapan awal dalam partisipasi masyarakat dalam PUMD P2HP. Dalam petunjuk teknis menjelaskan bahwa Kelompok Pengelola dan Pemasar harus diberikan sosialisasi mengenai Bantuan Langsung PUMD P2HP yang akan dilaksanakan. Hal itu bertujuan agar semua kelompok yang ada di satu Kabupaten/Kota memiliki informasi yang sama dan kesempatan yang sama dalam penerimaan Bantuan Langsung tersebut. Dalam Keputusan Direktur Jenderal Pengolahan dan Pemasaran Hasil Perikanan Nomor KEP.312/DJ-P2HP/2012 tentang Pedoman Teknis Pengembangan Usaha Mina Pedesaan Pengolahan dan Pemasaran Hasil Perikanan Tahun 2012 dijelaskan bahwa dalam rangka implementasi pelaksanaan PUMPP2HP maka perlu dilakukan sosialisasi kepada pemangku kepentingan antara lain 
POKLAHSAR, Tenaga Pendamping, Tim Teknis dan Tim Pembina. Kegiatan sosialisasi bertujuan untuk menginformasikan dan menyamakan persepsi mengenai langkah-langkah pelaksanaan PUMP-P2HP baik di tingkat pusat maupun daerah. Sosialisasi dilakukan antara lain melalui :

1. Pertemuan dengan mengundang para pemangku kepentingan;

2. Kunjungan lapangan oleh Pokja PUMP-P2HP;

3. Publikasi melalui pembuatan Pedoman, Leaflet/Brosur.

Kondisi yang terjadi di Bogor adalah Sosialisasi yang terjadi hanya sebatas 10 Kelompok Pengelola dan Pemasar yang telah ditunjuk oleh Dinas Peternakan dan Perikanan Kabupaten Bogor. Hal itu seperti yang diungkapkan oleh Salah satu pegawai Dinas Peternakan dan Perikanan Kabupaten Bogor yang menangani program PUMD P2HP. Hal itu disebabkan untuk efektifitas program sebab Kelompok pengelola dan pemasar terdiri dari masyarakat pendidikan rendah serta kelompok yang ditunjuk merupakan kelompok yang dianggap bisa dibina. Hal itu seiring dengan pendapat Metyer(2007) bahwa hubunganantara partisipasi dengan efektifitas kebijakan berbentuk kurva $U$ terbalik. Hal itu menunjukkan bahwa ada titik balik antara partisipasi dan efektifitas sehingga ketika partisipasi mencapai jumlah maksimal tertentu maka efektifitas akan menurun. Namun seharusnya penujukkan sepihak pada tahap sosialisasi tidak perlu dilakukan karena menyebabkan keterbatasan informasi dan ketimpangan informasi terhadap kelompok lain.

Sedangkan Sosialisasi isu berupa penetapan masalah yang dihadapi oleh kelompok Pengelola dan Pemasar, Sehingga solusi terhadap prioritas masalah yang akan diselesaikan tertuang dalam Rencana Usaha Bersama(RUB). Dalam pelaksanaan RUB seharusnya melibatkan partisipasi masyarakat berupa keterlibatan seluruh anggota kelompok dan tenaga pendamping. Penetapan pendamping yang berasal dari daerah setempat juga dianggap sebagai bentuk partisipasi masyarakat. Verhangen (1979) dalam Mardikanto (2003) 
menyatakan bahwa, partisipasi merupakan suatu bentuk khusus dari interaksi dan komunikasi yang berkaitan dengan pembagian: kewenangan, tanggung jawab, dan manfaat. Theodorson dalam Mardikanto (1994) mengemukakan bahwa dalam pengertian sehari-hari, partisipasi merupakan keikutsertaan atau keterlibatan seseorang (individu atau warga masyarakat) dalam suatu kegiatan tertentu baik sebagai pihak yang memperoleh dampak maupun hanya sebagai pelaksana yang mendapat imbalan atau tidak. Sehingga tenaga pendamping bisa dikategorikan sebagai partisipasi masyarakat.

Tenaga pendamping yang berfungsi sebagai pengawas dan pembimbing kelompok sasaran yang berasal dari non pemerintah. Sehingga keterlibatan masyarakat dalam bentuk tenaga pendamping akan memberikan hasil berupa:

1. Program dan pelaksanaannya lebih aplikatif terhadap konteks sosial, ekonomi dan budaya yang sudah ada, sehingga memenuhi kebutuhan masyarakat.

2. Menciptakan rasa memiliki dan tanggung jawab diantara semua pihak terkait dalam merencanakan dan melaksanakan program

3. memberikan peran bagi semua orang untuk terlibat dalam semua proses kebijakan, khususnya dalam pengawasan dan pelaksanaan.

4. Transparansi semakin terbuka lebar akibat penyebaran informasi dan wewenang. Peran tenaga pendamping dalam pelaksanaan PUMP-P2HP meliputi a. Mendampingi POKLAHSAR dalam menyusun Rencana Usaha Bersama (RUB); b. Menghubungkan POKLAHSAR dengan Tim Teknis; c. Membimbing pelaksanaan kegiatan pengembangan usaha pengolahan dan pemasaran POKLAHSAR; d. Memotivasi peran serta anggota POKLAHSAR dalam pengembangan kegiatan usaha pengolahan dan pemasarannya; e. Membantu POKLAHSAR dalam mengakses teknologi, informasi pasar, peluang usaha, permodalan dan sarana produksi; f. Mendampingi dan membantu POKLAHSAR dalam membangun kemitraan dengan pelaku usaha pengolahan dan pemasarannya; g. Membantu 
memecahkan permasalahan yang dihadapi POKLAHSAR; h. Membantu penumbuhan dan pengembangan kelembagaan POKLAHSAR; i. Mendampingi POKLAHSAR dalam penyusunan laporan. Sehingga terlihat bahwa peran masyarakat(Tenaga Pendamping dan POKLAHSAR) dalam perencanaan kebijakan terletak pada tahapan penetapan Rencana Usaha Bersama.

Sedangkan tahapan partisipasi masyarakat(Tenaga Pendamping) pada tahapan tahapan pengusulan dan penetapan POKLAHSAR terbagi atas yaitu pengusulan dan penetapan calon penerima BLM PUMP-P2HP yang dilakukan secara berjenjang. Dalam Keputusan Direktur Jenderal Pengolahan dan Pemasaran Hasil Perikanan Nomor KEP.312/DJ-P2HP/2012 tentang Pedoman Teknis Pengembangan Usaha Mina Pedesaan Pengolahan dan Pemasaran Hasil Perikanan Tahun 2012 dijelaskan bahwa ada beberapa keterlibatan tenaga pendamping yaitu sebagai berikut :

1. Tim Teknis dan Tenaga pendamping melakukan identifikasi, seleksi dan verifikasi usulan calon kelompok penerima BLM PUMP-P2HP.

2. Berdasarkan hasil identifikasi, seleksi dan verifikasi calon kelompok penerima BLM PUMP-P2HP, Tim Teknis mengusulkan calon kelompok penerima BLM PUMPP2HP kepada Tim Pembina dengan tembusan kepada Pokja PUMP-P2HP. Tim Pembina mengkoordinasikan usulan calon kelompok penerima BLM PUMP dari Dinas Kabupaten/Kota di wilayahnya dan Tim Pembina mengusulkan calon kelompok penerima BLM PUMP kepada Kepala Dinas Provinsi yang selanjutnya oleh Kepala Dinas Provinsi diusulkan kepada Pokja. Pokja memverifikasi ulang usulan calon kelompok penerima BLM PUMP untuk selanjutnya diusulkan kepada Direktur Jenderal terkait. Direktur Jenderal selaku penanggung jawab program menetapkan kelompok penerima BLM PUMP dengan Keputusan Direktur Jenderal. 
Direktur Jenderal selaku penanggung jawab program melaporkan penetapan penerima BLM PUMP kepada Tim Koordinasi.

\section{Proses Pengambilan Kebijakan}

Dalam proses pengambilan kebijakan PUMD P2HP, partisipasi masyarakat telah dibatasi untuk pelaksanaan teknis karena kebijakan ini bersifat Top-Down maka secara garis besar hanya berupa penggunaan dana bantuan langsung sesuai menu yang telah ditetapkan yaitu hanya boleh menggunakan dana untuk pengadaan peralatan pengelolaan dan pemasaran. Sehingga masukkan masyarakat hanya berupa penurunan/spsifikasi dari pembiayaan pengadaan barang pengelolaan. Padahal masyarakat lebih menginginkan bantuan berupa tambahan modal untuk bahan produksi seperti ikan dan perbaikan lokasi pengelolaan. Namun karena sudah dibatasi dengan aturan yang berlaku seperti yang tertuang dalam Keputusan

Direktur Jenderal Pengolahan dan Pemasaran Hasil Perikanan Nomor KEP.312/DJP2HP/2012 tentang Pedoman Teknis Pengembangan Usaha Mina Pedesaan Pengolahan dan Pemasaran Hasil Perikanan Tahun 2012 maka tidak bisa dilakukan sesuai prioritas kebutuhan Kelompok Pengelola tersebut.

Seharusnya pengambilan kebijakan merupakan pilihan terhadap alternatif kebijakan yang memiliki skala prioritas tertinggi. Fish Bones menjelaskan bahwa dapat dilakukan melalui runut sebagai berikut 1) penetapan pohon masalah. Misalnya POKLAHSAR menghadapi permasalahan kekurangan pemasok ikan, kekurangan modal bahan produksi, keterbatasan peralatan pengelolaan. 2)Analisa sasaran. Tahapan ini melihat sasaran yang ingin dicapai kemudian di rumuskan. Apakah sasaran yang dicaai merupakan permasalahan inti atau permasalahan yang muncul akibat permasalahan inti. 3) Rumusan Alternatif. Alternatif yang ada diberikan skala prioritas. Sehingga ditemukan Kebijakan yang paling sesuai. Rencana Usaha Bersama(RUB PUMD P2HP) dianggap belum mampu menerapkan pendekatan 
tersebut sebab walaupun sudah dilakukan melalui rapat bersama tetapi hasilnya tidak dapat dijadikan kebijakan karena dibatasi oleh peraturan(adanya paket menu dalam Petunjuk Teknis PUMD P2HP).

Sehingga Partisipasi masyarakat dalam pengambilan keputusan hanya berada pada tahap penggunaan dana tersebut. Dalam pelaksanaan BLM PUMP-P2HP, rapat anggota (RA) merupakan forum tertinggi dalam pengambilan keputusan. Hal-hal yang diputuskan pada RA, diantaranya memilih dan memberhentikan pengurus, penambahan anggota, pengesahan program, penetapan unit usaha, evaluasi pengembangan pengelolaan unit usaha POKLAHSAR dan hal lain yang perlu mendapatkan kesepakatan anggota. Rapat Anggota merupakan forum pertemuan yang dihadiri oleh seluruh anggota dan setiap anggota memiliki hak suara yang sama. Sebagai forum tertinggi dalam pelaksanaan PUMP-P2HP di tingkat POKLAHSAR, Rapat Anggota dilaksanakan dengan mekanisme sebagai berikut:

1. Rapat Anggota dihadiri oleh seluruh pengurus dan anggota POKLAHSAR serta Tenaga Pendamping

2. Rapat anggota dilaksanakan secara periodik sesuai kesepakatan anggota.

3. Tujuan rapat anggota adalah untuk menetapkan :

a. RUB (Rencana Usaha Bersama);

b. Mekanisme pemanfaatan dana BLM PUMP-P2HP;

c. Usaha produktif pengolahan dan pemasaran;

d. Tata tertib rapat anggota;

e. Pengesahan pertanggungjawaban pengurus.

Selain itu, partisipasi masyarakat(Tenaga Pendamping) dalam proses pengambilan keputusan dalam penetapan POKLAHSAR di Bogor juga tidak berlangsung seperti yang seharusnya. 6 POKLAHSAR yang terpilih adalah hasil penunjukkan oleh Dinas Peternakan dan Perikanan kota Bogor tanpa melakukan seleksi terhadap kelompok lain. Hal ini akibat penunjukkan 
pada tahapan awal(sosialisasi) yang hanya melibatkan 6 POKLAHSAR, sedangkan seharusnya ada 75 Kelompok yang mengikuti tahapan seleksi penerimaan bantuan tersebut. Seperti yang diungkapkan sebelumnya, hal tersebut terjadi karena keterbatasan pendidikan POKLAHSAR Bogor. Sehingga penetapan langsung dinilai oleh Pemerintah Kabupaten sebagai tindakan efektif. Namun kondisi tersebut menyebabkan partisipasi Tenaga Pendamping yang seharusnya terlibat dalam penentuan POKLAHSAR penerima bantuan tidak terpenuhi. Seharusnya dalam Keputusan Direktur Jenderal Pengolahan dan Pemasaran Hasil Perikanan Nomor KEP.312/DJ-P2HP/2012 tentang Pedoman Teknis Pengembangan Usaha Mina Pedesaan Pengolahan dan Pemasaran Hasil Perikanan Tahun 2012 emnjelaskan bahwa pengusulan dan penetapan calon penerima BLM PUMP-P2HP dari aspirasi masyarakat dilakukan melalui tahapan seperti dibawah ini:

a. usulan calon kelompok penerima BLM PUMP dari usulan aspirasi masyarakat disampaikan kepada Pokja;

b. Pokja menginventarisir usulan calon kelompok penerima BLM PUMP dan menugaskan Tim Teknis untuk melakukan verifikasi;

\section{Partisipasi Masyarakat Dalam Monitoring}

Pada dasarnya monitoring atau pemantauan yang ada dalam PUMD P2HP lebih banyak terletak pada jenjang pemerintah mulai dari pemerintah pusat (Tim Koordinasi dan Pokja PUMP-P2HP), pemerintah propinsi (Tim Pembina), hingga di pemerintah Kabupaten/Kota tim teknis Pengendalian kegiatan PUMP-P2HP juga dilakukan dengan berbasis elektronik berupa database yang dikelola Pokja PUMP-P2HP. Database PUMPP2HP mencakup : Database POKLAHSAR, Tenaga Pendamping dan Kegiatan PUMP-P2HP. Pokja PUMP-P2HP melakukan pengendalian terhadap pelaksanaan PUMP-P2HP melalui 
pertemuan dan kunjungan lapangan ke Provinsi dan Kabupaten/Kota untuk menjamin pelaksanaan kegiatan sesuai dengan kebijakan umum Menteri sekaligus menyelesaikan permasalahan yang terjadi di lapangan. Namun pada kondisi dilapangan Pokja hanya datang kebeberapa lokasi saja mengingat keterbatas dana, Sumberdaya Manusia, dan Waktu. Sehingga pemantauan lebih banyak dilakukan oleh pemerintah daerah.

Sedangkan untuk partisipasi masyarakat dapat dilihat berdasarkan Keputusan Direktur Jenderal Pengolahan dan Pemasaran Hasil Perikanan Nomor KEP.312/DJ-P2HP/2012 tentang Pedoman Teknis Pengembangan Usaha Mina Pedesaan Pengolahan dan Pemasaran Hasil Perikanan Tahun 2012 maka dapat disimpulkan bahwa ada 2 bentuk partisipasi masyarakat dalam proses monitoring yaitu terbagi atas keterlibatan POKLAHSAR dan Tenaga Pendamping. Keterlibatan POKLAHSAR berupa bantuan dalam seleksi,identifikasi,verifikasi POKLAKSAR penerima bantuan PUMD P2HP. Namun karena POKLAHSAR di Bogor sudah di tetakan oleh Dinas Peternakan dan Perikanan maka partisipasi dimulai pada tahappan identifikasi dan verifikasi. Identifikasi dan verifikasi bertujuan untuk membantu POKLAHSAR dalam menentukan pengunaan dana Bantuan. Verifikasi terhadap RUB dan dokumen administrasi lainnya dilakukan dan disetujui oleh Tim Teknis bersama-sama dengan tenaga pendamping di tingkat Kabupaten/Kota.

Selain itu, tenaga pendamping berfungsi untuk mengawasi penyaluran dana kepada POKLAHSAR dan penggunaan pada saat proses pembelian peralatan. Prosedur Penyaluran Dana BLM PUMP-P2HP diantaranya yaitu: 1)KPA Satker Direktorat Usaha dan Investasi melakukan proses penyaluran dana BLM PUMP-P2HP kepada POKLAHSAR sesuai dengan persyaratan dan kelengkapan dokumen yang telah ditetapkan; 2). Penyaluran dana BLM PUMP-P2HP dilakukan dengan mekanisme Pembayaran Langsung (LS) ke Rekening POKLAHSAR ;3). KPA menerbitkan Surat Perintah Kerja (SPK) bermaterai Rp. 6.000,- kepada POKLAHSAR.4). KPA atau PPK mengajukan Surat Permohonan 
Pembayaran Langsung (SPP-LS) kepada Pejabat Penandatangan Surat Perintah Membayar (SPM);5). Pejabat Penandatangan SPM mengajukan Surat Perintah Membayar Langsung (SPM-LS) ke Kantor Pelayanan Perbendaharaan Negara (KPPN) Jakarta I dengan melampirkan : a) Surat Pernyataan Tanggung Jawab Belanja (SPTJB) yang ditandatangani oleh KPA Satker Direktorat Usaha dan Investasi atau PPK Subdit Ketenagakerjaan Pengolahan dan Pemasaran ;b) Rekapitulasi pembayaran kepada POKLAHSAR penerima dana BLM PUMP-P2HP yang ditandatangani oleh KPA Satker Direktorat Usaha dan Investasi atau PPK Subdit Ketenagakerjaan Pengolahan dan Pemasaran; c) Surat Perintah Kerja (SPK); d) Berita Acara Pembayaran e) Keputusan Direktur Jenderal tentang Penetapan POKLAHSAR.6. Berdasarkan SPM-LS, KPPN I Jakarta menerbitkan SP2D ke rekening POKLAHSAR melalui Bank Operasional KPPN sesuai ketentuan berlaku.

Untuk menghindari terjadinya kerjasama dalam penyimpangan dana baik oleh POKLAHSAR, Tim Pendamping dan Dinas Peternakan dan Perikanan Kabupaten Bogor maka Dinas Peternakan dan Perikanan Kabupaten Bogor memberikan ketentuan tambahan yaitu semua buku tabungan yang digunakan sebagai penerima dana harus dipegang oleh Dinas.

Sedangkan partisipasi POKLAHSAR hanya sebatas pada kelompok yang menerima bantuan sedangkan Kelompok Pengelola dan Pemasar lain yang tidak mendapat program ini tidak memiliki akses untuk berpartisipasi dalam monitoring. Hal itu disebabkan beberapa hal diantaranya sosialisasi yang tidak dilakukan secara menyeluruh, tidak ada aturan yang menunjukkan bahwa hasil verifikasi diumumkan secara transparan mengenai bobot penilaian yang menyebabkan suatu Kelompok yang mengajukan diterima atau tidak. 
Daftar Pustaka

Durn,Durning. 1993. Partisipatory Analisys Social Service Agency; A Case Study, Jurnal of Policy Analysis and Management Ndraha, T. 1987. Pembangunan Masyarakat Mempersiapkan Masyarakat Tinggal Landas. Jakarta: BinaAksara.

Dunn,William. 2003.Pengantar Analisa Kebijakan Publik Edisi Kedua. Yogyakarta: Gajah Mada Press Solichin. 1998. Analisis Kebijakan Publik Teori dan Aplikasinya. Fakultas Ilmu Administrasi Brawijaya.

Tosun. 2006. Expected Nature Of Community Participation In Tourism Development, (School Of Tourism and Hotel Management, Turkey)

Westra,Pariata. 1977. Beberapa Masalah Di Dalam Hubungan Kerja Kemanusiaan(Human Relation). Yogyakarta: UGM Yogyakarta 


\section{Lampiran:}

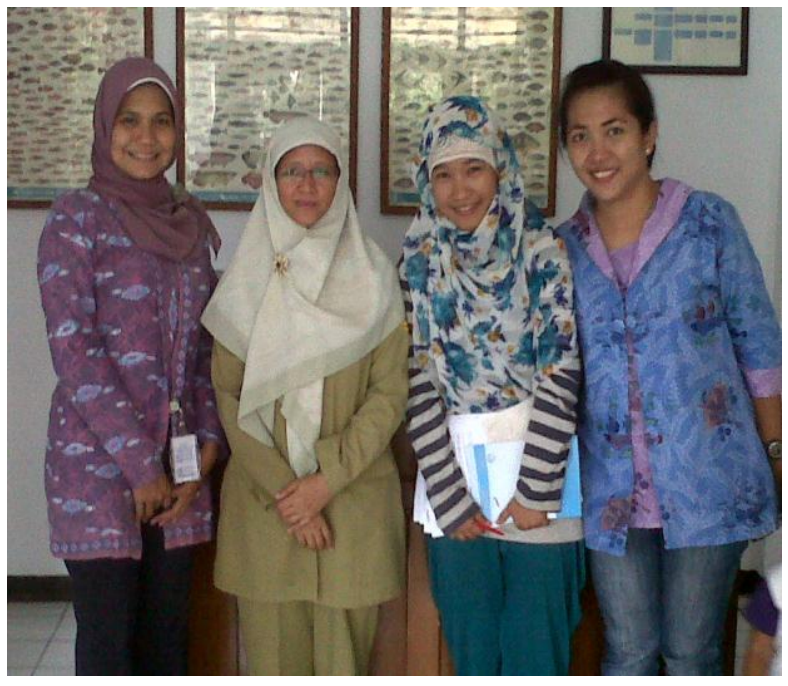

Kunjungan Di Dinas Peternakan dan Perikanan Kab.Bogor

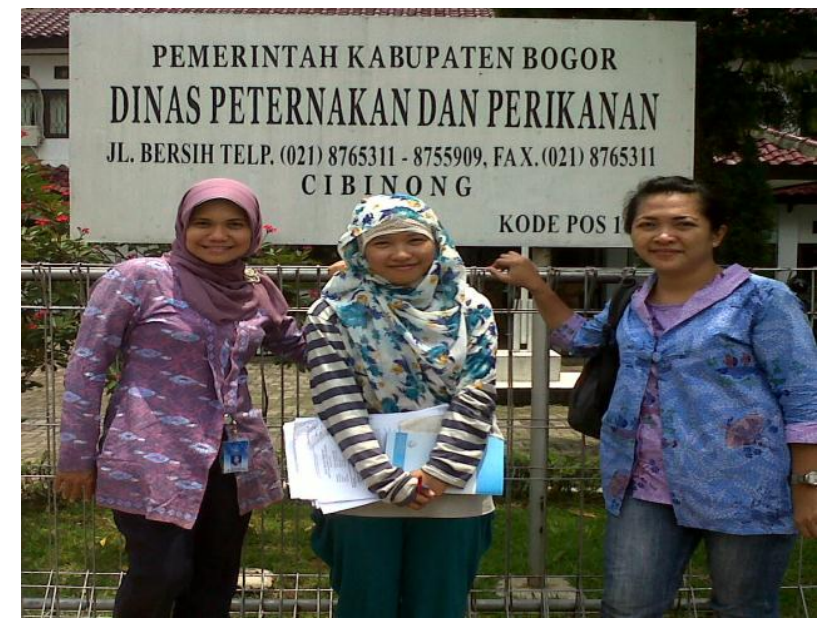

Kunjungan Di Dinas Peternakan dan Perikanan Kab.Bogor

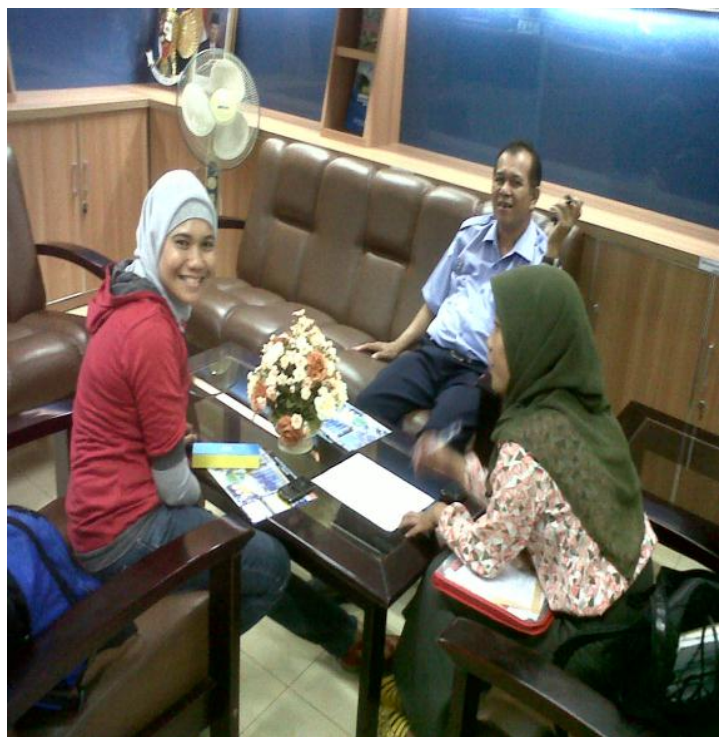

Kunjungan di Kementrian Kelautan dan Perikanan

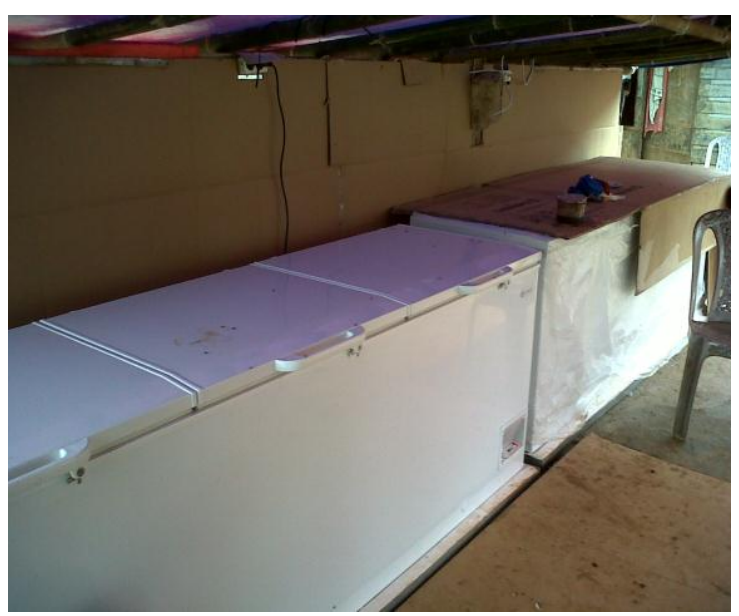

Frezeer Box (Kunjungan ke POKLAHSAR Mandiri dan Sawah Murti, Parung) 